\title{
Advanced molecular characterization of enteropathogenic Escherichia coli isolated from diarrheic camel neonates in Egypt
}

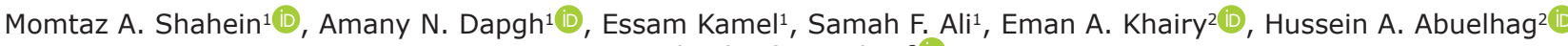 \\ and Ashraf S. Hakim²
}

\begin{abstract}
1. Animal Health Research Institute, Agriculture Research Center, Dokki, Giza, Egypt; 2. Department of Microbiology and Immunology, National Research Centre, 33 Bohouth St., Dokki, Cairo, Egypt.

Corresponding author: Amany N. Dapgh, e-mail: amany.nabil.dapgh@gmail.com

Co-authors: MAS: momtaz.shahein@yahoo.com, EK: essamkamel1@yahoo.com, SFA: samah_hefny2004@yahoo.com, EAK: emankhairy_77@yahoo.com, HAA: drabouelhag@yahoo.com, ASH: migris410@yahoo.com
\end{abstract}

Received: 31-08-2020, Accepted: 25-11-2020, Published online: 12-01-2021

doi: www.doi.org/10.14202/vetworld.2021.85-91 How to cite this article: Shahein MA, Dapgh AN, Kamel E, Ali SF, Khairy EA, Abuelhag HA, Hakim AS (2021) Advanced molecular characterization of enteropathogenic Escherichia coli isolated from diarrheic camel neonates in Egypt, Veterinary World, 14(1): 85-91.

\begin{abstract}
Background and Aim: Camels are important livestock in Egypt on cultural and economic bases, but studies of etiological agents of camelid diseases are limited. The enteropathogen Escherichia coli is a cause of broad spectrum gastrointestinal infections among humans and animals, especially in developing countries. Severe infections can lead to death. The current study aimed to identify pathogenic $E$. coli strains that cause diarrhea in camel calves and characterize their virulence and drug resistance at a molecular level.

Materials and Methods: Seventy fecal samples were collected from diarrheic neonatal camel calves in Giza Governorate during 2018-2019. Samples were cultured on a selective medium for E. coli, and positive colonies were confirmed biochemically, serotyped, and tested for antibiotic susceptibility. E. coli isolates were further confirmed through detection of the housekeeping gene, yai $\mathrm{O}$, and examined for the presence of virulence genes; $\operatorname{tra\mathrm {T}}$ and $f i m \mathrm{H}$ and for genes responsible for antibiotic resistance, $a m p \mathrm{C}, a a d \mathrm{~B}$, and $m p h \mathrm{~A}$. The isolates in the important isolated serotype, E. coli $\mathrm{O} 26$, were examined for toxigenic genes and sequenced.

Results: The bacteriological and biochemical examination identified 12 E. coli isolates from 70 fecal samples (17.1\%). Serotyping of these isolates showed four types: O26, four isolates, 33.3\%; O103, O111, three isolates each, 25\%; and O45, two isolates, $16.7 \%$. The isolates showed resistance to vancomycin (75\%) and ampicillin (66.6\%), but were highly susceptible to ciprofloxacin, norfloxacin, and tetracycline $(100 \%)$. The structural gene, yai $(115 \mathrm{bp})$, was amplified from all $12 \mathrm{E}$. coli isolates and $\mathrm{tra \textrm {T }}$ and $\mathrm{fim} \mathrm{H}$ genes were amplified from 10 and 8 isolates, respectively. Antibiotic resistance genes, $a m p \mathrm{C}, m p h \mathrm{~A}$, and $a a d \mathrm{~B}$, were harbored in $9(75 \%), 8(66.6 \%)$, and $5(41.7 \%)$, respectively. Seven isolates $(58.3 \%)$ were MDR. Real-time-polymerase chain reaction of the $\mathrm{O} 26$ isolates identified one isolate harboring $v t 1$, two with $v t 2$, and one isolate with neither gene. Sequencing of the isolates revealed similarities to E. coli $\mathrm{O} 157$ strains.
\end{abstract}

Conclusion: Camels and other livestock suffer various diseases, including diarrhea often caused by microbial pathogens. Enteropathogenic E. coli serotypes were isolated from diarrheic neonatal camel calves. These isolates exhibited virulence and multiple drug resistance genes.

Keywords: camel, multidrug-resistant Escherichia coli, real-time polymerase chain reaction, sequencing, virulence.

\section{Introduction}

One-humped Arabian camel (Camelus dromedarius) livestock is widely distributed in the Middle East; the animal is well adapted to semi-arid and arid environments. In Egypt, camel herds are important semi-domestic animals heavily used in tourist safaris and transportation and for milk and meat [1].

Escherichia coli is a Gram-negative rod in Enterobacteriaceae. The bacterium is considered an important constituent of gut microbiota in birds and mammals. However, various strains of this species

Copyright: Shahein, et al. Open Access. This article is distributed under the terms of the Creative Commons Attribution 4.0 International License (http://creativecommons.org/licenses/ by/4.0/), which permits unrestricted use, distribution, and reproduction in any medium, provided you give appropriate credit to the original author(s) and the source, provide a link to the Creative Commons license, and indicate if changes were made. The Creative Commons Public Domain Dedication waiver (http:// creativecommons.org/publicdomain/zero/1.0/) applies to the data made available in this article, unless otherwise stated. are pathogenic and cause various gastrointestinal disorders, such as diarrhea [2]. In Egypt, diarrheagenic E. coli (DEC), especially Shiga toxin-producing E. coli, are described in livestock, including calves, sheep, goat, and buffalo calves [3-5]. However, few studies of DEC in camels are available.

Some strains of DEC are public health concerns and may be transmitted from livestock (e.g., camels) to humans. Gastrointestinal infection may cause nonbloody or bloody diarrhea, hemorrhagic colitis (HC), and hemolytic uremic syndrome. These illnesses threaten millions of peoples worldwide, especially in developing countries [6].

Pathogenic E. coli diagnosis requires differentiation from non-pathogenic strains that are constitutive components of normal intestinal flora. Such pathotypes are defined by the presence of one or more definable $E$. coli virulence factors and can be identified by advanced molecular and certain conventional 
methods [7]. Molecular techniques are more rapid and precise for the identification of bacteria compared with conventional phenotypic methods. Multiplex polymerase chain reaction (mPCR) and quantitative real-time PCR (qRT-PCR) are typically used for identification of bacterial species. Further, sequence analysis is an accurate approach for species delineation and epidemiological tracking [8].

Detection of specific genes is fundamental for diagnosis, confirmation, and/or investigation of virulence and antibiotic resistance of $E$. coli isolates; yaiO is a housekeeping gene in $E$. coli orphan open reading frame that encodes a protein originally expressed and localized in the outer membrane [9]. tra $\mathrm{T}$ is a virulence factor and a constituent of conjugative plasmids that encodes a surface protein responsible for entry exclusion [10]. An essential step for initiation and development of enteritis is bacterial attachment to intestinal epithelial cells. E. coli attachment is mediated by fimbriae (adhesins) that bind to host cell receptors; the Fim $\mathrm{H}$ gene is representative [11].

Resistance of microorganism to multiple antimicrobial drugs is a global threat that interferes with and prolongs therapy. Pathogenic E. coli strains characteristically harbor antibiotic resistance genes. $M p h \mathrm{~A}$ is responsible for production of macrolide 2'-phosphotransferase I that inactivates 14-ring macrolides, such as erythromycin and oleandomycin [12]. Another drug resistance gene, $A m p C$, encodes AmpC $\beta$-lactamase that degrades penicillins [13]. $a a d B$ is responsible for the production of 2'-aminoglycoside nucleotidyltransferase enzyme that inactivates aminoglycoside antibiotics [14].

Studies of molecular characteristics of $E$. coli isolates from camel herds in Egypt are limited. The current study explores pathogenic E. coli among diarrheic camel calves using advanced molecular techniques.

\section{Materials and Methods \\ Ethical approval}

As per CPCSEA guidelines, a study involving clinical and postmortem samples does not require the approval of the Institute Animal Ethics Committee.

\section{Sampling}

Seventy fecal samples were collected from neonatal camel calves raised for meat production. Calves were under 6 months of age and suffered from diarrhea. Calves were raised in the Giza Governorate during 2018-2019. Swabs were immediately placed in cooled boxes, transported to the laboratory, and incubated overnight at $37^{\circ} \mathrm{C}$ in trypticase soy broth (Merck KgaA, Darmstadt, Germany).

\section{Isolation and identification of $E$. coli}

Each sample was streaked onto MacConkey's agar (Merck, Germany) and incubated for $24 \mathrm{~h}$ at $37^{\circ} \mathrm{C}$. Lactose-positive colonies were similarly incubated on eosin methylene blue agar (EMB, Merck, Germany). We used two selective media because
EMB is used for selection because it is specific for $E$. coli, and MacConkey is for lactose fermentation.

Green colonies with a metallic luster were considered E. coli; such colonies were further identified using the API 20E system (BioMérieux, France) following the manufacturer's instructions to obtain biochemical profiles of isolates.

The isolates were serologically identified by "Seikin" E. coli O-antigen diagnostic antisera (polyvalent and monovalent vials, product code; 312001) following the manufacture's instructions.

\section{Antibiogram E. coli isolates}

$E$. coli isolates were tested for phenotypical susceptibility to frequently used veterinary antibiotics trough disk diffusion method on Mueller-Hinton agar plates (Oxoid, UK) following the guidelines of the Clinical and Laboratory Standards Institute [15]. A panel of 15 antibiotic disks was used: Cefotaxime $(30 \mu \mathrm{g})$, cefazolin $(30 \mu \mathrm{g})$, trimethoprim/sulfamethoxazole $(25 \mu \mathrm{g})$, sulfaprim $(50 \mu \mathrm{g})$, ampicillin $(10 \mu \mathrm{g})$, amoxicillin $(10 \mu \mathrm{g})$, erythromycin $(15 \mu \mathrm{g})$, vancomycin $(15 \mu \mathrm{g})$, amikacin $(30 \mu \mathrm{g})$, streptomycin $(30 \mu \mathrm{g})$, gentamycin $(10 \mu \mathrm{g})$, ciprofloxacin $(5 \mu \mathrm{g})$, norfloxacin $(10 \mu \mathrm{g})$, cefadroxil $(30 \mu \mathrm{g})$, and tetracycline $(10 \mu \mathrm{g})$.

\section{Molecular diagnosis of $E$. coli isolates}

Polymerase chain reaction (PCR)

DNA extraction

DNA was extracted from $E$. coli isolates using a QIAamp DNA Mini kit (Qiagen, Germany, GmbH) with modifications from the manufacturer's recommendations. Briefly, $200 \mu \mathrm{L}$ of sample suspension was incubated with $10 \mu \mathrm{L}$ of proteinase $\mathrm{K}$ and $200 \mu \mathrm{L}$ of lysis buffer at $56^{\circ} \mathrm{C}$ for $10 \mathrm{~min}$. After incubation, $200 \mu \mathrm{L}$ of $100 \%$ ethanol was added to the lysate. The sample was then washed and centrifuged following the manufacturer's instructions. Nucleic acid was eluted with $100 \mu \mathrm{L}$ of elution buffer provided in the kit.

Oligonucleotide primer

Primers used were supplied from Metabion (Germany) (Table-1) $[9,16,17]$.

\section{PCR amplification}

Primers were used in a $50 \mu \mathrm{L}$ PCR reaction containing $25 \mu \mathrm{L}$ of EmeraldAmp Max PCR Master Mix (Takara, Japan), $1 \mu \mathrm{L}$ of each primer (20 pmolar), $9 \mu \mathrm{L}$ of water, and $10 \mu \mathrm{L}$ of DNA template. The reactions were uniplex (yaiO) [9], diplex (tra T and fim $\mathrm{H})$ [16], and multiplex $(\operatorname{ampC}, \operatorname{aad} \mathrm{B}$, and $m p h \mathrm{~A})$ [17] (Table-1) using a Biometra thermal cycler.

\section{Analysis of the PCR products}

The products of PCR were separated by electrophoresis in $1.5 \%$ agarose gels (Applichem, Germany, $\mathrm{GmbH})$ in $\times 1$ Tris/Borate/ethylenediaminetetraacetic acid buffer at room temperature using gradients of 5 $\mathrm{V} / \mathrm{cm}$. Thirty microliters of PCR product was loaded in each gel slot. A 100 bp ladder (Qiagen, Germany, $\mathrm{GmbH}$ ) was used to determine fragment sizes. The gel 


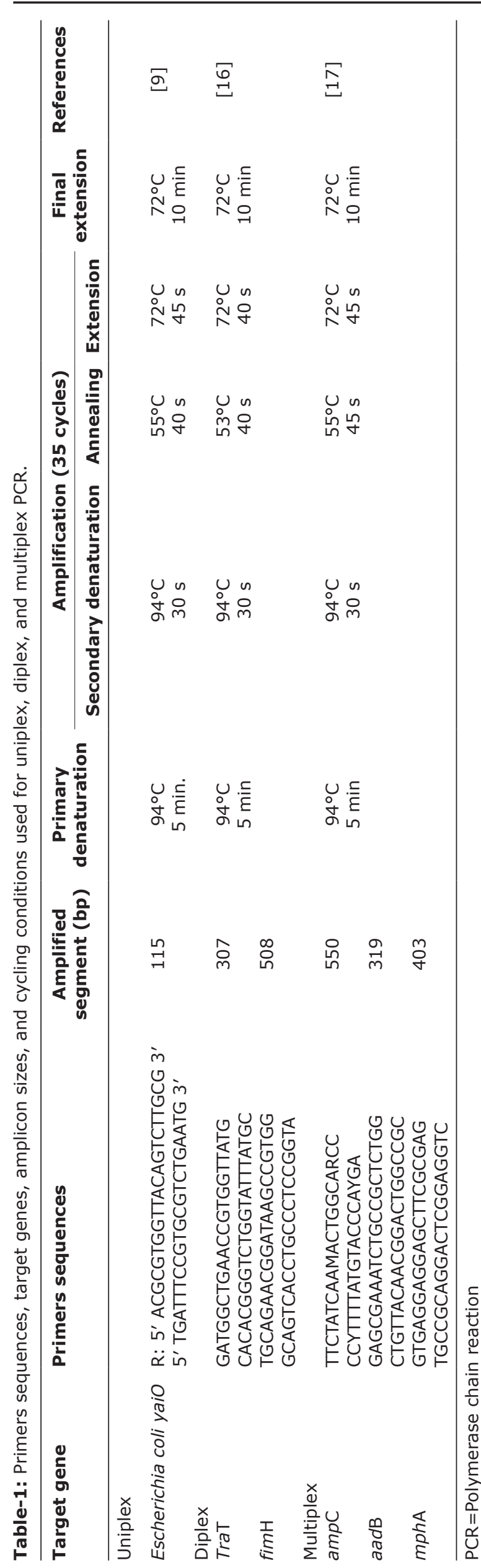

was photographed using a gel documentation system (Alpha Innotech, Biometra, Germany), and data were analyzed with computer software. Reference $E$. coli strains ATCC35150 and HB 101 were used as a positive control and Staphylococcus aureus ATCC29737 as a negative control.

\section{RT-PCR}

Positive E. coli $\mathrm{O} 26$ samples were extracted using a Sigma kit following kit instructions. RT-PCR using a MTplexdtec-RT-qPCR Test (Edifici-Quórum3, Spain) that includes $v t 1$ and $v t 2$ genes with $v t$ specific primers and probes (Table-2) [18]. Signal was collected, and reactions run in an Applied Biosystem StepOne RT-PCR System. FAM fluorogenic cycle threshold of reactions was identified using StepOne ${ }^{\mathrm{TM}}$ software (Life Technology, USA). The qualitative detection module analyzed the samples for the presence of $v t 1$ and $v t 2$ based on fluorescence levels above the background.

\section{E. coli DNA sequencing}

The amplified traT PCR fragments (307 bp) were excised from gels and the DNA extracted using ExoSAP-IT PCR Product Cleanup kit (Affymetrix, USA) following the manufacturer's instructions. Purified amplicons were sequenced with an ABI PRISM $^{\circledR}$ BigDyedye ${ }^{\mathrm{TM}}$ terminator cycle sequencing kit with AmpliTaq ${ }^{\circledR}$ DNA polymerase on an MJ Research PTC-225 Peltier Thermal Cycler (Applied Biosystems, USA) following manufacturer's recommendations. DNA sequences were identified by comparison with established sequences in GenBank.

\section{Results and Discussion}

The bacteriological and biochemical examination of the 70 fecal samples showed 12 E. coli isolate $(17.1 \%)$. These results are similar to the findings of Hussni et al. [19], who reported a prevalence of enteropathogenic and enterotoxigenic $E$. coli in camel fecal samples in Qatar of $21.1 \%$. This incidence was slightly higher than $12.3 \%$ of pathogenic E. coli found in Kenya [20]. Conversely, the prevalence in our study was much higher than among 140 fecal samples collected from camels in the United Arab Emirates(4.3\%) [21] and 3.8\% among 600 fecal samples collected from camels in Nigeria [22].

Twelve E. coli isolates displayed four; four from serogroup O26 (33.3\%), three each from O103 and O111 (25\%), and two from O45 (16.7\%). These results are somewhat consistent with Adamu et al. [22], who found that $\mathrm{O} 26$ was the main serotype in camel fecal samples $(43.5 \%)$ with lesser incidence of $\mathrm{O} 103$ and O111 serotypes (17.4\% and $13.0 \%$, respectively); the O45 serogroup was not detected. Conversely, the O45 serotype was frequently encountered in camel feces by Hussni et al. [18]. The serotype O103 was detected along with other serotypes $\mathrm{O} 2, \mathrm{O} 8, \mathrm{O} 83$, and $\mathrm{O} 120$ in diarrheic camel calves [23].

$E$. coli isolates were more frequently resistant to vancomycin (75\%) and ampicillin $(66.6 \%)$. However, 
significant resistance was also observed to amoxicillin $(58.3 \%)$ and streptomycin $(50 \%)$. In contrast, isolates were found to be highly sensitive to ciprofloxacin, norfloxacin, and tetracycline $(100 \%)$ and somewhat less sensitive to gentamycin and trimethoprim-sulfamethoxazole $(83.3 \%)$. Previous evaluation of pathogenic $E$. coli isolates for antibiotic resistance varies. Bessalah et al. [24] indicated that E. coli isolates were sensitive to ciprofloxacin, gentamicin, amikacin, chloramphenicol, and ceftiofur and resistant to ampicillin and tetracycline. Further, E. coli isolates were $100 \%$ susceptible to ciprofloxacin, norfloxacin, cefotaxime, chloramphenicol, and polymyxin B [21].

yaiO is a housekeeping gene of E. coli, and its detection confirms that isolates are E. coli strains. The intended $115 \mathrm{bp}$ band was amplified in all 12 isolates to confirm E. coli (Figure-1). Molina et al. [9] reported that yai $\mathrm{O}$ amplification is highly specific for E. coli, with superior detection ability and non-redundancy with enzymatic methods.

The presence of the virulence genes is indicative of the pathogenicity of E. coli strains and is used to distinguish such strains from non-pathogenic bacteria. tra $\mathrm{T}$ is important for conjugal transfer in E. coli, encodes a complement resistance protein, and is responsible for preventing unproductive conjugation between bacteria carrying plasmids [10]. Moreover, adherence of $E$. coli to host receptors confers resistance to mechanical elimination and increases persistence. fim $\mathrm{H}$ is a major determinant encoding adhesins that target epithelial receptors; thus, the gene is crucial for E. coli colonization [11]. Results obtained from diplex
PCR (Figure-2) recognized tra $\mathrm{T}$ and fim $\mathrm{H}$ genes in 8 and 10 isolates $(75 \%, 83.3 \%)$, respectively. Moreover, all four isolates of serotype $\mathrm{O} 26$ harbored both virulence genes. The three isolates of serotype $\mathrm{O} 103$ carried $\operatorname{fim} \mathrm{H}$, but only one carried the traT gene. Two of three isolates of serotype $\mathrm{O} 111$ carried tra $\mathrm{T}$ and $\operatorname{fim} \mathrm{H}$ and the two $\mathrm{O} 45$ isolates harbored one gene each. Similar data were reported by Díaz-Jiménez et al. [25], who indicated that about $85 \%$ of $E$. coli isolates implicated diarrheic conditions carried tra $\mathrm{T}$ and $\operatorname{fim} \mathrm{H}$ genes. Staji et al. [26] showed that the traT gene is common enteropathogenic (EPEC) and enterohemorrhagic E. coli (EHEC) ink serotypes O26 and O111. Further, the fim $\mathrm{H}$ gene was expressed in enteropathogenic E. coli strains of zoonotic importance [27] and in multidrug-resistant diarrheagenic strains [28].

The emergence of multidrug-resistant strains is important for economic concerns as well as a public health [29]. The 12 E. coli isolates were checked for the presence of three prevalent antibiotic resistance genes (Figure-3). All 12 isolates harbored at least one gene. Nine carried $a m p \mathrm{C}(75 \%)$, eight $m p h \mathrm{~A}(66.6 \%)$, and five $a a d \mathrm{~B}(41.7 \%)$. Two isolates harbored all three genes $(25 \%)$, showed the O26 serotype. Five isolates carried two genes $(41.7 \%)$. These data indicate that 7 isolates $(58.3 \%)$ could be considered MDR. Interestingly, genotypic results are harmonized with the phenotype of one isolate; high and intermediate resistance to vancomycin, ampicillin, amoxicillin, and streptomycin. Multidrug resistance for this combination among DEC strains is frequently reported $(80 \%$, $94 \%$, and $78.1 \%$ ) [30-32], respectively.

Table-2: Real-time PCR: Primer sequences, target gene, and amplicon sizes.

\begin{tabular}{lccc}
\hline Sequence & Target gene & Amplified segment (bp) & References \\
\hline F(ATAAATCGCCATTCGTTGACTAC) & $v t 1$ & 180 & {$[18]$} \\
R(AGAACGCCCACTGAGATCATC) & $v t 2$ & 255 & \\
F(GGCACTGTCTGAAACTGCTC) & & & \\
R(TCGCCAGTATCTGACATTCTG) & & & \\
\hline
\end{tabular}

$\mathrm{PCR}=$ Polymerase chain reaction

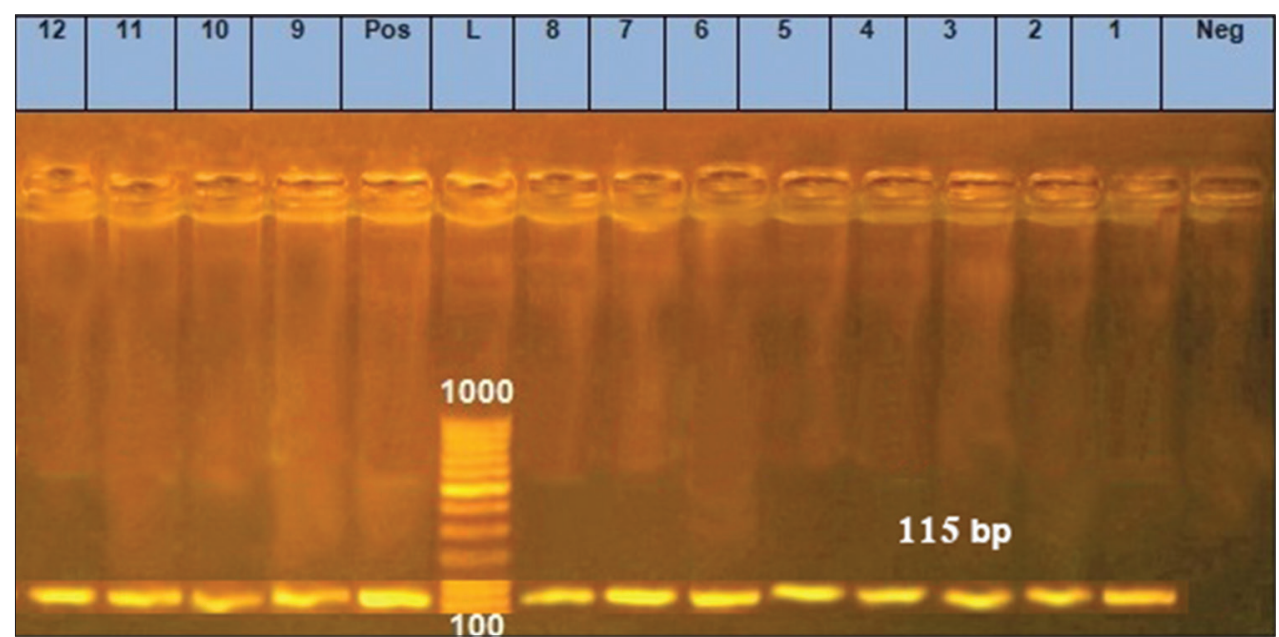

Figure-1: Uniplex polymerase chain reaction detection of structural gene in Escherichia coli isolates showing: L: 100 bp DNA ladder. Lanes 1-12: E. coli isolates. Lane pos.: Positive control; amplification of 115 bp represented yaiO, lane neg.: Negative control. 


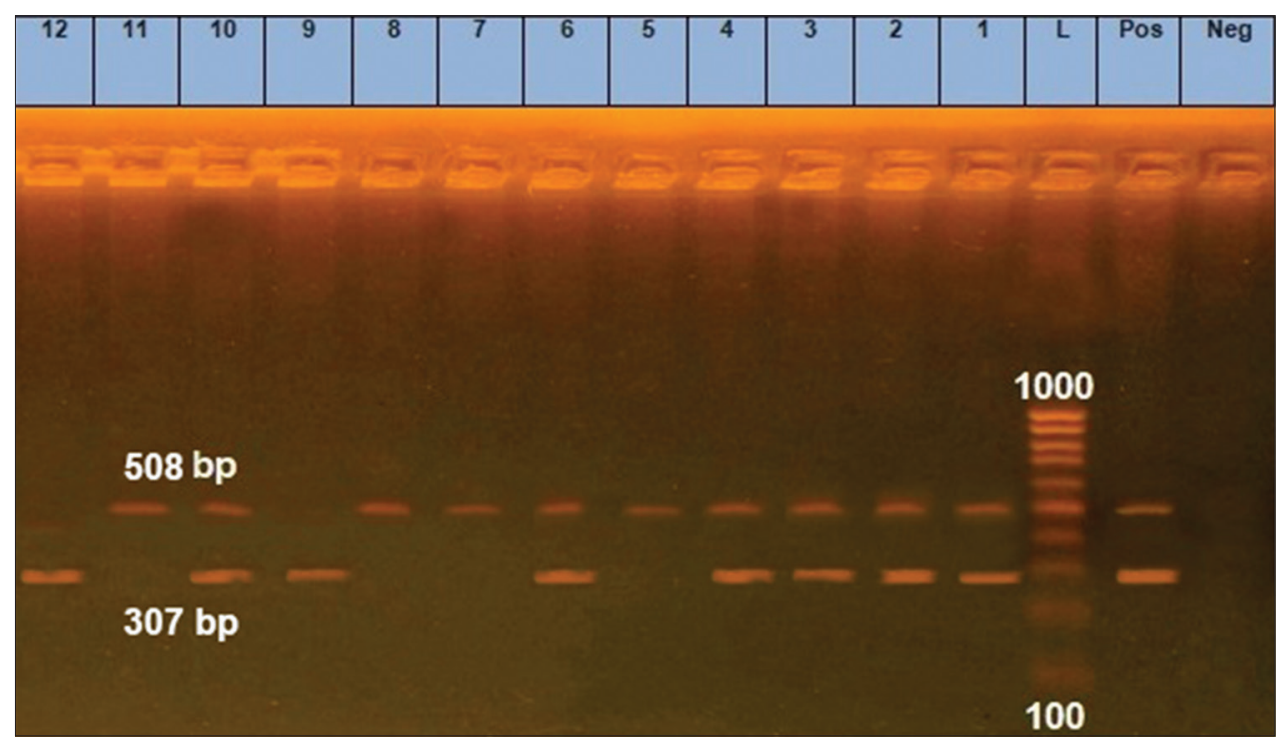

Figure-2: Diplex polymerase chain reaction detection of Shiga toxins genes in Escherichia coli isolates showing: L: $100 \mathrm{bp}$ DNA ladder. Lane neg.: Negative control, lane pos.: Positive control; lanes 1-12 E. coli isolates (1-4; 026), (5-7; 0103), $(8-10 ; 0111)$ and $(11-12 ; 045)$, amplification of 307 bp represented traT, 508 bp represented fim $\mathrm{H}$.

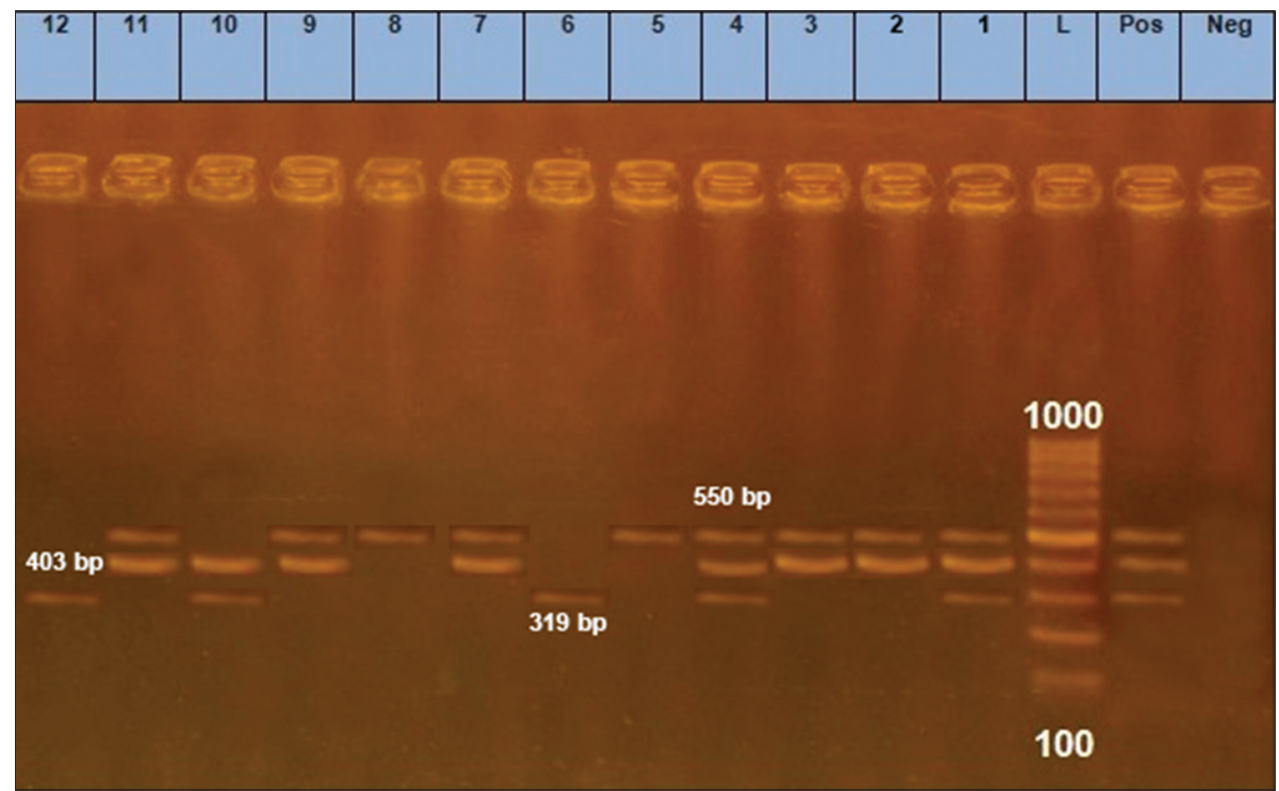

Figure-3: Multiplex polymerase chain reaction detection of antibiotic-resistant genes in Escherichia coli isolates showing: L: 100 bp DNA ladder. Lane neg.: Negative control, lane pos.: Positive control; lanes 1-12 E. coli isolates (1-4; 026), (5-7; 0103), (8-10; 0111), and (11-12; 045); amplification of 319 bp represented aadB, 403 bp represented $m p h A$, and 550 bp represented ampC.

Pathogenic and toxigenic E. coli are implicated in many disorders in animals, such as diarrhea and HC. The O26 serotype is the second most significant pathogenic serotype worldwide after O157:H7, since it produces toxins and causes zoonotic disease. The four $\mathrm{O} 26$ isolates were given more attention in the present study. These isolates were positive for $v t 1$ and $v t 2$, genes responsible for verocytotoxin expression. One isolate was positive for targeting $v t 1$ at cycle 32 , and three isolates were positive for targeting $v t 2$. Previous reports also show an association between enterotoxigenic E. coli $\mathrm{O} 26$ strains and the presence of verotoxigenic genes $[18,33]$.

DNA sequence was initially performed to establish identity to sequences in GenBank. E. coli $\mathrm{O} 26$
GH1, 2, 3, and 4 were selected for similarity to virulence traT gene with genes in GenBank. Sequence alignments using NCBI BLASTP indicated close identity of $E$. coli $\mathrm{O} 26 \mathrm{GH} 1$ virulence tra T with $E$. coli_O157:H7_EC4115 (98.4\%) and E. coli O26 GH2 with $E$. coli with $E$. coli_K_12_C3026 (97.5\%). Both E. coli $\mathrm{O} 26 \mathrm{GH} 3$ and E. coli $\mathrm{O} 26 \mathrm{GH} 4$ showed identity with E. coli_O157:H7_TW14359 (97.7\%). These results are supported by other investigations that indicate that $E$. coli $\mathrm{O} 26$ is an enterotoxigenic $E$. coli group related to $E$. coli O157 [34-36].

\section{Conclusion}

In spite of camel has unique circumstances, but as other livestock suffer from different diseases, 
including diarrhea, caused by microbial agents. Enteropathogenic E. coli serotypes isolated from diarrheic neonatal camel calves displayed virulence and multidrug resistance, the ability to produce toxins, and possible importance for zoonotic disease transmission.

\section{Authors' Contributions}

MAS and AND designed the study. HAA and EAK collected samples and then performed the bacterial isolation and biochemical typing. ASH conducted serological typing. HAA and EAK performed DNA extraction and PCR. SFA and AND fulfilled the qRT-PCR, while EK and SFA implemented sequencing. MAS and AND analyzed the data, ASH and AND drafted the manuscript, revised, and finalized the manuscript for submission. All authors read and approved the final manuscript.

\section{Acknowledgments}

The authors are thankful to Animal Health Research Institute and National Research Centre, Egypt, for providing the infrastructure for conducting the study. The authors did not receive any funds for this study.

\section{Competing Interests} interests.

The authors declare that they have no competing

\section{Publisher's Note}

Veterinary World remains neutral with regard to jurisdictional claims in published institutional affiliation.

\section{References}

1. Hoter, A., Rizk, S. and Naim, H.Y. (2019) Cellular and molecular adaptation of Arabian camel to heat stress. Front. Genet., 10: 588.

2. Zade, H.A., Teshnizi, S.H., Azad, M., Shojae, S., Gouklani, H., Davoodian, P. and Ghanbarpour, R. (2019) An overview of diarrheagenic Escherichia coli in Iran: A systematic review and meta-analysis. J. Res. Med. Sci., 24: 23.

3. Osman, K.M., Mustafa, A.M., Elhariri, M. and El-Hamed, G.S.A. (2013) The distribution of Escherichia coli serovars, virulence genes, gene association and combinations and virulence genes encoding serotypes in pathogenic $E$. coli recovered from diarrheic calves, sheep and goat. Transbound. Emerg. Dis., 60(1): 69-78.

4. Galal, H.M., Hakim, A.S. and Dorgham, M.S. (2013) Phenotypic and virulence genes screening of Escherichia coli strains isolated from different sources in delta Egypt. Life Sci. J., 10(2): 352-361.

5. Hakim, A.S., Omara, S.T., Syame, S.M. and Fouad, E.A. (2017) Serotyping, antibiotic susceptibility, and virulence genes screening of Escherichia coli isolates obtained from diarrheic buffalo calves in Egyptian farms. Vet. World, 10(7): 769-773.

6. Emmanuel, W.B., McAllister, T.A., Zaheer, R., Polo, R.O., Stanford, K., King, R., Niu, Y.D. and Collins, N.A. (2019) Characterization of Non-O157 Escherichia coli from cattle fecal samples in the North-West Province of South Africa. Microorganisms, 7(8): 272.

7. Stromberg, R.Z., Van Goor, A., Redweik, G.A.J., Brand, M.J., Wannemuehler, M.J. and Mellata, M. (2018)
Pathogenic and non-pathogenic Escherichia coli colonization and host inflammatory response in a defined microbiota mouse model. Dis. Model Mech., 11(11): dmm035063.

8. Fadlelmula, A., Al-Hamam, N.A. and Al-Dughaym, A.M. (2016) A potential camel reservoir for extended-spectrum $\beta$-lactamase-producing Escherichia coli causing human infection in Saudi Arabia. Trop. Anim. Health Prod., 48(2): 427-433.

9. Molina, F., López-Acedo, E., Tabla, R., Roa, I., Gómez, A. and Rebollo, J. (2015) Improved detection of Escherichia coli and coliform Bacteria by multiplex PCR. BMC Biotechnol., 15: 48.

10. Nüesch-Inderbinen, M., Käppeli, N., Morach, M., Eicher, C., Corti, S. and Stephan, R. (2019) Molecular types, virulence profiles and antimicrobial resistance of Escherichia coli causing bovine mastitis. Vet. Rec. Open, 6(1): e000369.

11. Li, D., Shen, M., Xu, Y., Liu, C., Wang, W., Jinyan, W.U., Luo, X. and Ma, Y.X. (2018) Virulence gene profiles and molecular genetic characteristics of diarrheagenic Escherichia coli from a hospital in western China. Gut. Pathog., 10(1): 35.

12. Cheng, Y., Yang, S., Jia, M., Zhao, L., Hou, C., You, X., Zhao, J. and Chen, A. (2016) Comparative study between macrolide regulatory proteins $\mathrm{MphR}(\mathrm{A})$ and $\mathrm{MphR}(\mathrm{E})$ in ligand identification and DNA binding based on the rapid in vitro detection system. Anal. Bioanal. Chem., 408(6): 1623-1631.

13. Richter, L., Erika, M., Plessis, D., Duvenage, S. and Korsten, L. (2020) Occurrence, phenotypic and molecular characterization of extended-spectrum-and AmpC$\beta$-lactamase producing Enterobacteriaceae isolated from selected commercial Spinach supply chains in South Africa. Front. Microbiol., 11: 638.

14. Sarker, M.S., Ahad, A., Ghosh, S.K., Mannan, M.S., Sen, A., Islam, S., Bayzid, M. and Bupasha, Z.B. (2019) Antibiotic-resistant Escherichia coli in deer and nearby water sources at Safari parks in Bangladesh. Vet. World, 12(10): 1578-1583.

15. Clinical and Laboratory Standards Institute. (2020) Performance Standards for Antimicrobial Susceptibility Testing: Twenty-second Informational Supplement M100-S30. Clinical and Laboratory Standards Institute, Wayne.

16. Paniagua-Contreras, G.L., Monroy-Pérez, E., Bautista, A., Reyes, R., Vicente, A., Vaca-Paniagua, F., Estela Díaz, C., Martínez, S., Domínguez, P., Rey García, L., UribeGarcía, A. and Vaca, S. (2018) Multiple antibiotic resistances and virulence markers of uropathogenic Escherichia coli from Mexico. Pathog. Glob. Health, 112(8): 415-420.

17. Lindsey, R.L., Garcia-Toledo, L., Fasulo, D., Gladney, L.M. and Strockbine, N. (2017) Multiplex polymerase chain reaction for identification of Escherichia coli, Escherichia albertii and Escherichia fergusonii. J. Microbiol. Methods, 140: $1-4$

18. Thomas, K.M., McCann, M.S., Collery, M.M., Logan, A., Whyte, P., McDowell, D.A. and Duffy, G. (2012) Tracking verocytotoxigenic Escherichia coli O157, O26, O111, O103 and O145 in Irish cattle. Int. J. Food Microbiol., 153(3): 288-296.

19. Hussni, O.M., Korana S., Salem, A., Mcdonough, P., Chang, Y.F. and Sultan, A. (2015) Risk of Escherichia coli O157:H7, non-O157 Shiga toxin-producing Escherichia coli, and Campylobacter spp. in food animals and their products in Qatar. J. Food Prot., 78(10): 1812-1818.

20. Baschera, M., Cernela, N., Mja, S., Liljander, A., Jores, J., Corman, V.M., Nüesch-Inderbinen, M. and Stephan, R. (2019) Shiga toxin-producing Escherichia coli (STEC) isolated from fecal samples of African dromedary camels. One Health, 7: 100087.

21. Al-Ajmi, D., Rahman, S. and Banu, S. (2020) Occurrence, virulence genes, and antimicrobial profiles of Escherichia coli $\mathrm{O} 157$ isolated from ruminants slaughtered in $\mathrm{Al}$ Ain, 
United Arab Emirates. BMC Microbiol., 20(1): 210.

22. Sakuma, A.M., Ugochukwu, I.C., IdokoIdoko, S., Kwabugge, Y.A., Nafisatu, S.A. and Ameh, A.J. (2018) Virulent gene profile and antibiotic susceptibility pattern of Shiga toxin-producing Escherichia coli (STEC) from cattle and camels in Maiduguri, North-Eastern Nigeria. Trop. Anim. Health Prod., 50(6): 1327-1341.

23. Chauhan, R.S. and Kaushik, R.K. (1991) Isolation of enterotoxigenic Escherichia coli from camels with diarrhea. Vet. Microbiol., 29(2): 195-197.

24. Bessalah, S., Morris, J., Fair, B., Salhi, I., Vanier, G., Touhami, K., Seddik, M.M. and Hammadi, M. (2016) Antimicrobial resistance and molecular characterization of virulence genes, phylogenetic groups of Escherichia coli isolated from diarrheic and healthy camel-calves in Tunisia. Comp. Immunol. Microbiol. Infect., 49: 1-7.

25. Díaz-Jiménez, D., García-Meniño, I., Herrera, A., García, V., López-Beceiro, A.M., Alonso, M.P., Blanco, J. and Mora, A. (2020) Genomic characterization of Escherichia coli isolates belonging to a new hybrid aEPEC/ ExPEC pathotype O153:H10-A-ST10 eae-beta1 occurred in meat, poultry, wildlife and human diarrheagenic samples. Antibiotics (Basel), 9(4): 192.

26. Staji, H., Badagliacca, P., Salehi, T.Z., Lopes, F., Iorio, M., Tonelli, A. and Masson, L. (2017) Pathotyping of diarrhoeagenic cattle Escherichia coli strains isolated in the Province of Tehran, Iran. Vet. Ital., 53(4): 345-356.

27. Arais, L.R., Barbosa, A.V., Andrade, J.R.C., Gomes, T.A.T., Asensi, M.D., Aires, C.A.M. and Cerqueira, A.M.F. (2018) Zoonotic potential of atypical enteropathogenic Escherichia coli (aEPEC) isolated from puppies with diarrhea in Brazil. Vet. Microbiol., 227: 45-51.

28. Tharwat, N., El-Sherif, R., Elnagdy, S., Marzaban, R. and Amer, S. (2019) Virulent Escherichia coli strains among Egyptian patients with acute diarrhea versus urinary tract infection, and their antibiotic susceptibility. Arab. J. Gastroenterol., 20(2): 74-80.
29. Oliveira, J. and Reygaert, W.C. (2020) Gram-negative Bacteria In: StatPearls. StatPearls Publishing, Treasure Island, FL.

30. Iweriebor, B.C., Iwu, C.J., Obi, L.C., Nwodo, U.U. and Okoh, A.I. (2020) Multiple antibiotic resistances among Shiga toxin producing Escherichia coli $\mathrm{O} 157$ in feces of dairy cattle farms in Eastern Cape of South Africa. Infect. Drug Resist., 13(13): 1387-1396.

31. Tellevik, M.G., Blomberg, B., Kommedal, Ø., Maselle, S.Y., Langeland, N. and Moyo, S.J. (2015) High prevalence of fecal carriage of ESBL-producing Enterobacteriaceae among children in Dar es Salaam, Tanzania. $B M C$ Microbiol., 16(15): 213.

32. Abbasi, E., Mondanizadeh, M., van Belkum, A. and Ghaznavi-Rad, E. (2016) Multi-Drug-resistant diarrheagenic Escherichia coli pathotypes in pediatric patients with gastroenteritis from central Iran. PLoS One, 11(12): e0168024.

33. Nobili, G., Franconieri, H., Bella, B.L., Basanisi, G.M. and Salandra, G. (2017) Prevalence of verocytotoxigenic Escherichia coli strains isolated from raw beef in southern Italy. Int. J. Food Microbiol., 18(257): 201-205.

34. Kang, S., Ravensdale, J.T., Coorey, R., Dykes, G.A. and Barlow, R.S. (2020) Analysis of bacterial diversity in relation to presence of Top 7 Shiga toxin-producing Escherichia coli throughout Australian beef abattoirs. J. Food Prot., 83(10): 1812-1821.

35. Rapp, D., Ross, C.M., Maclean, P., Cave, V.M. and Brightwell, G. (2020) Investigation of On-Farm Transmission Routes for Contamination of Dairy Cows with Top 7 Escherichia coli O-Serogroups, Microb. Ecol., doi: 10.1007/s00248-020-01542-5.

36. Thierry, S.I.L., Gannon, J.E., Jaufeerally-Fakim, Y. and Santchurn, S.J. (2020) Shiga-toxigenic Escherichia coli from animal food sources in Mauritius: Prevalence, serogroup diversity and virulence profiles. Int. J. Food Microbiol., 2(324): 108589. 